\title{
Penetration and Pullout Capacity of Low-Skirted Suction Caissons
}

\author{
Mingyuan Wang, Xiaoke Liu, ${ }^{2}$ Xinglei Cheng $\mathbb{D}^{1},{ }^{3}$ Qun $L u,{ }^{3}$ Jiaqing Lu, ${ }^{3}$ and Miao Wang ${ }^{3}$ \\ ${ }^{1}$ POWERCHINA Huadong Engineering Corporation Limited, Hangzhou 310014, China \\ ${ }^{2}$ North China Municipal Engineering Design and Research Institute Co., Ltd., Tianjin 300381, China \\ ${ }^{3}$ Key Laboratory of Soft Soil Engineering Character and Engineering Environment of Tianjin, Tianjin Chengjian University, \\ Tianjin 300384, China \\ Correspondence should be addressed to Xinglei Cheng; chengxinglei110@163.com
}

Received 11 June 2021; Revised 14 July 2021; Accepted 24 August 2021; Published 6 September 2021

Academic Editor: Angelo M. Tusset

Copyright (c) 2021 Mingyuan Wang et al. This is an open access article distributed under the Creative Commons Attribution License, which permits unrestricted use, distribution, and reproduction in any medium, provided the original work is properly cited.

\begin{abstract}
The bearing capacity of suction caissons is the key to the design of offshore structures. A new type of cross-shaped low-skirted suction caisson is invented to effectively improve the bearing capacity, considering inevitable "soil plug" phenomenon. The behaviors of penetration and pullout for new low-skirted suction caisson are investigated by performing model tests. A new formula for calculating the penetration resistance is suggested based on the limit equilibrium theory and the test data, which can consider the change of the lateral area of the suction caisson during penetration. The behaviors of low-skirted suction caisson under inclined loading are analyzed by carrying out finite element simulation. The effects of loading angles and loading positions on the ultimate bearing capacity and failure mechanism of low-skirted suction caissons are discussed. The research results can provide a reference for the design of suction bucket foundation for offshore structures.
\end{abstract}

\section{Introduction}

Offshore oil production platforms and wind turbines need to anchor the superstructure to the seabed by some anchor foundations to resist the marine environmental loads. The bearing capacity of anchor foundations is the key to the design of offshore structures [1]. These anchor foundations include suction caissons, plate anchors, and large diameter monopiles. The suction caisson as one type of important offshore foundations has been widely used in practical engineering projects because of its many advantages including low construction cost, fast and low-noisy installation, and reusability $[2,3]$.

The regular suction caisson is a hollow cylinder without a bottom, just like an upside-down bucket. The suction caisson first is penetrated into the seabed by its self-weight and ballast and then is penetrated furtherly using negative pressure by pumping out continuously the water entrapped in the compartment [4]. The pullout capacity is the key to the design of suction caissons subjected to tensile loading. Asa and Andersen [5] studied the bearing capacity and failure mode of the suction caisson. Clukey et al. [6] studied the failure behaviors of suction caissons in normally consolidated clays by conducting centrifuges. Many researches including model tests and numerical simulations have been carried out to study the pullout capacity of suction bucket caissons under vertical loads, horizontal loads, bending moment loads, and the combination of these loads [7-13]. Many analytical approaches such as limit equilibrium method [14, 15], finite element analysis method [16-18], and finite element limit analysis method [19-21] have been proposed to investigate the pullout behaviors of suction caissons. The behaviors of installation and penetration of suction caissons were also studied by Sun et al. [22] and Zhu et al. [23] by performing model tests.

Some new types of suction bucket structures have been developed to improve their bearing capacity. A modified skirted suction caisson consisting of an internal compartment combined with an upper external short-skirted compartment was developed by Li et al. [24] to increase the bearing capacity of the regular one. A series of studies on pullout capacity of the modified skirted suction caisson 
under vertical, lateral, and moment loadings have been investigated by $\mathrm{Li}$ et al. $[25,26]$. A new type of umbrella suction caisson was developed by Liu and Li [27] and Li et al. [28], and its bearing capacity and dynamic characteristics were investigated by performing model tests and numerical simulation. A composite bucket shallow foundation was proposed by Tianjin University to adapt the offshore soft geological conditions of China for wind turbines, and the bearing capacity and technical advantages of composite bucket foundation have been investigated by performing a series of model tests and finite element analysis $[29,30]$.

There are still some problems in actual installation of the suction caisson, such as "soil plug" phenomenon, although it has many advantages. In this paper, a new type of crossshaped low-skirted suction caisson is invented by the authors to effectively improve the bearing capacity considering inevitable "soil plug" phenomenon. The behaviors of penetration and pullout for new low-skirted suction caissons are investigated by performing model tests, and then the failure mechanisms of low-skirted suction caisson under inclined loading are discussed by carrying out finite element analysis.

\section{Model Tests of Low-Skirted Suction Caissons}

2.1. Low-Skirted Suction Caisson Model. Four suction caisson models were used in this experiment, as shown in Figure 1. No. 1 is a conventional single-bucket suction caisson. No. 2 and No. 3 suction buckets are common T-shaped skirted suction caissons, which consist of an internal compartment combined with an upper external shortskirted compartment to increase the bearing capacity [24]. No. 4 suction bucket is a new type of cross-shaped skirted suction caisson invented by the authors, which is called the low-skirted suction caisson. The phenomenon of "soil plug" often occurs during the penetration of suction caissons. A suitable height difference $\mathrm{H}_{3}$ is set between internal compartment and external compartment of the suction caisson when considering inevitable "soil plug", which can increase the penetration depth of the skirted compartment. The external skirted compartment can also better protect the soil around the internal compartment from being eroded by the ocean current, which is of great significance in improving the bearing capacity of suction caisson. There are holes connected to the vacuum pump on the top of the internal and external compartments to increase the penetration suction. All suction caisson models were made of PMMA transparent glass for the convenience of observing the "soil plug" during penetration. A guide bar was set on the top of the suction caisson to ensure the verticality of the suction caisson in the process of penetration. Detail sizes of four suction caisson models are shown in Table 1.

\subsection{Penetration of Suction Caissons}

2.2.1. Penetration Test Device and Method. The size of model tank is $1.0 \mathrm{~m} \times 0.9 \mathrm{~m} \times 0.8 \mathrm{~m}$ (length $\times$ width $\times$ height) in Figure 2. Calcareous low permeability kaolin clay is used in tests. The particle diameter is mainly between $0.005 \mathrm{~mm}$ and $0.1 \mathrm{~mm}$. The unit weight of soil is about $16 \mathrm{kN} / \mathrm{m}^{3}$. The plastic limit is $32 \%$ and the liquid limit is $59 \%$. The undrained shear strength profile is shown in Figure $3.30 \mathrm{~mm}$ thick gravel and $50 \mathrm{~mm}$ thick medium coarse sand were successively laid at the bottom of the tank. The steel wire threaded filter pipe with a diameter of $26 \mathrm{~mm}$ was embedded in gravel and the geotextile was laid at the interface of soil layer. The suction caisson was gradually penetrated into the soil using the negative pressure from the vacuum pump and filter bottle, and the displacement of suction caisson and negative pressure was measured by relevant monitoring system. The top of internal and external compartments for low-skirted suction caisson was connected to the vacuum pump during the penetration. The layout of four suction caissons is shown in Figure 4. The arrow lines connecting the buckets represent the penetration sequence of the buckets in the figure.

2.2.2. Penetration Test Results. The penetration depth of suction caissons with negative pressure is shown in Figure 5. It can be seen that the change trend of penetration depth is basically the same for these four caissons. The penetration depth increases gradually with the increase of negative pressure. At the beginning of penetration, the rate of penetration is relatively larger, then gradually slow down, and finally tends to zero. When the negative pressure approaches $50 \mathrm{kPa}$, the curves of penetration depth vs. negative pressure appear at an inflection point, which indicates that the top of suction caisson has come into contact with the mud surface, and the penetration resistance reaches the maximum. The curve of penetration depth versus negative pressure is similar to parabola. The final penetration negative pressure reached about $90 \mathrm{kPa}$. Compared with No. 1, No. 2, and No. 3 suction caissons, No. 4 suction caisson has the largest penetration depth, which means that the low-skirted suction caisson is easier to penetrate than other types. Enough negative pressure must be applied to the suction caisson during penetration. However, the negative pressure value should be controlled within a certain range to avoid the formation of excessive "soil plug" due to soil failure [23]. Therefore, when the maximum negative pressure is constant, the penetration depth of suction caisson depends on the effective area of negative pressure. The larger the effective area is, the greater the penetration force is, and hence the greater the final penetration depth is (obviously, the effective area of No. 4 caisson is larger than that of Nos. 1 3 caissons as shown in Figure 6), so the height of "soil plug" is relatively smaller.

Penetrations of four suction caissons at the same negative pressure of $P$ are shown in Figure 6. For No. 1 suction caisson, the seepage force caused by negative pressure makes the soil outside the caisson continuously pour into the caisson, resulting in "soil plug". For No. 2 and No. 3 suction caissons, the penetration rate of suction caisson reduces because of the obstruction of skirted caisson (no negative pressure on the external skirted compartment), and the time of seepage force is relatively prolonged, which leads to the increase of the height of "soil plug". Moreover, the skirted caisson higher than the mud surface results in waste of 


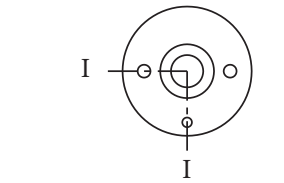

Thread hole of guide bar

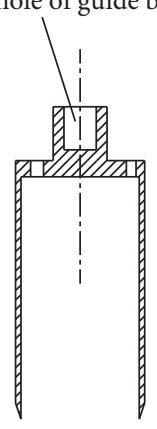

(a)
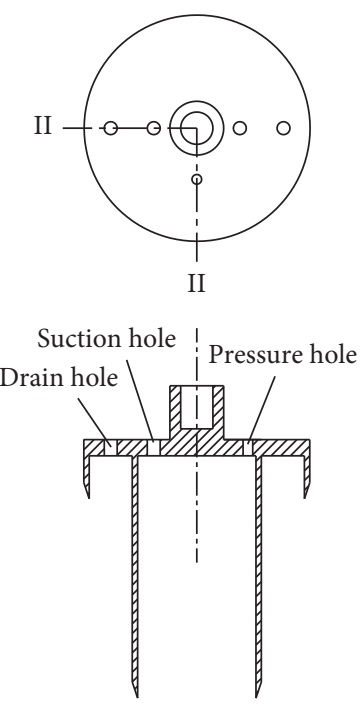

(b)
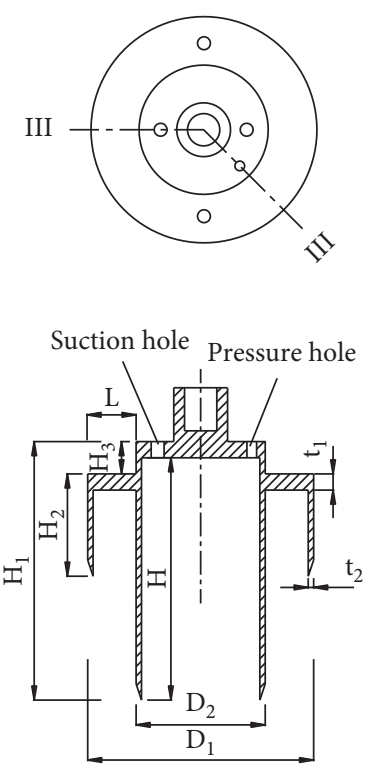

(c)

FIgure 1: Different suction caissons used in model tests: (a) conventional, (b) T-shaped skirted, and (c) cross-shaped low-skirted.

TABle 1: Detail size of suction caissons ( $\mathrm{mm}$ ).

\begin{tabular}{lcccccccc}
\hline Type & Model number & $D_{2}$ & $H_{1}$ & $D_{1}$ & $H_{2}$ & $H_{3}$ & $t_{1}$ \\
\hline Conventional & 1 & 120 & 255 & - & - & - & 15 \\
\hline \multirow{2}{*}{ T-shaped } & 2 & 120 & 255 & 200 & 55 & 0 & 15 \\
& 3 & 120 & 255 & 200 & 75 & 5 & 15 \\
\hline \multirow{2}{*}{ Cross-shaped } & 4 & 120 & 255 & 200 & 75 & 30 & 15 \\
\hline
\end{tabular}

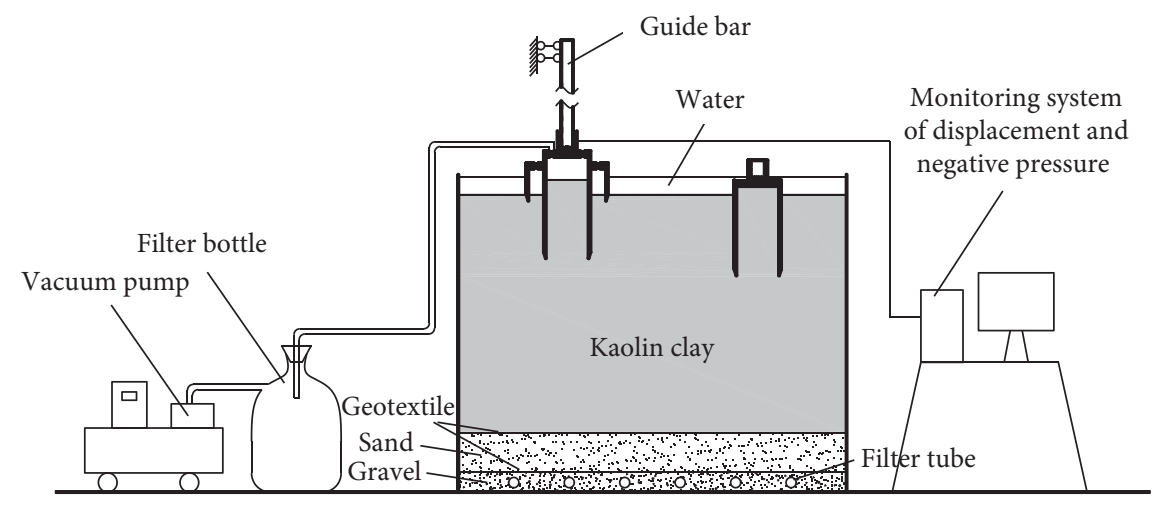

Figure 2: Penetration device schematic.

caisson material and the "water plug" is easily formed in the skirted compartment. For No. 4 suction caisson, because a certain height difference is set between the internal and external compartments of the suction caisson and the double compartment negative pressure penetration method is adopted, the penetration force is increased compared with No. 2 and No. 3 suction caissons. Hence, it can overcome the resistance and continue to penetrate and effectively reduce the height of "soil plug".

The time effect, that is, the influence of loading rate on the penetration results, is fully considered in this paper. The penetration rate of No. 1 , No. 3 , and No. 4 suction caissons is the same and maintained at $0.65 \mathrm{~mm} / \mathrm{min}$, while the penetration rate of No. 2 suction caisson is maintained at $0.35 \mathrm{~mm} / \mathrm{min}$ during the experiment. The curves of penetration depth with time are shown in Figure 7. It can be seen from the figure that the trend of the penetration depth-time curves for No. 1, No. 3, and No. 4 suction caissons is basically the same, and the "soil plug" is formed at about $180 \mathrm{~min}$, while the penetration rate of No. 2 suction caisson is relatively slow, and its "soil plug" is formed in about $270 \mathrm{~min}$. Hence, the penetration rate has a certain influence on the 


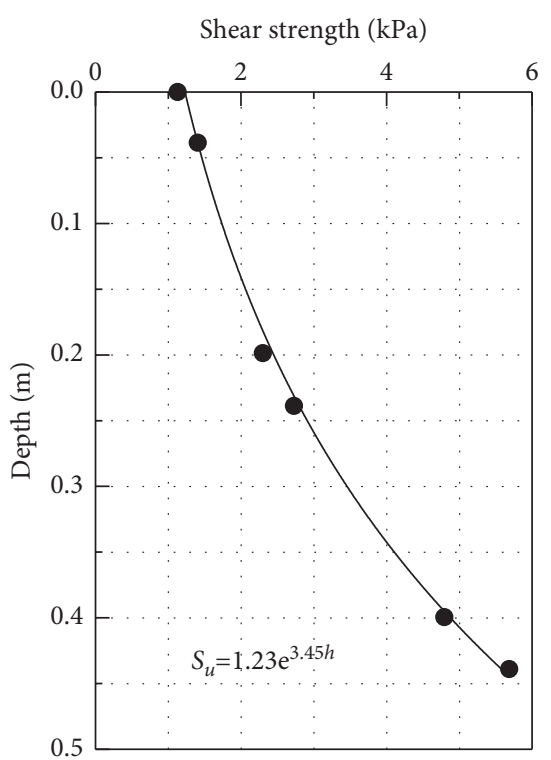

Figure 3: Vane shear strength profile of soil ( $h$ indicates the depth of the soil layer).

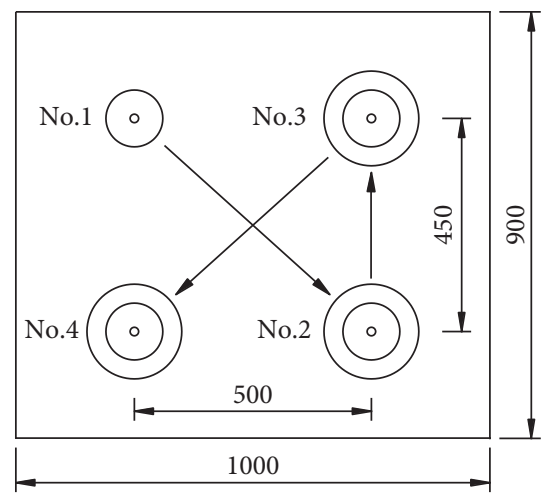

FIgURE 4: Layout of four suction caissons (length unit/mm).

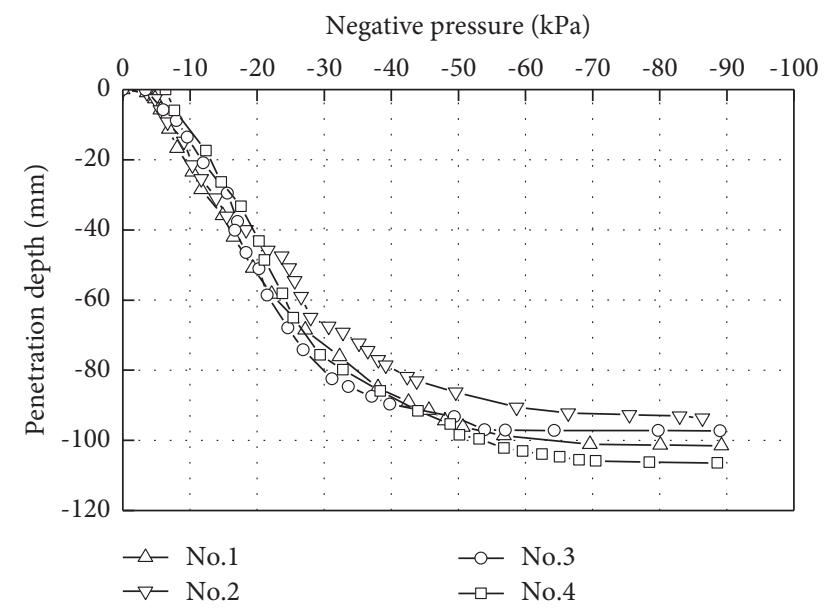

FIgURE 5: Penetration depth versus negative pressure for four suction caissons.

height of "soil plug". The dead-weight penetration depth (the penetration depth of the suction caisson under its gravity and the gravity of guide rod, valve, and pipeline), negative

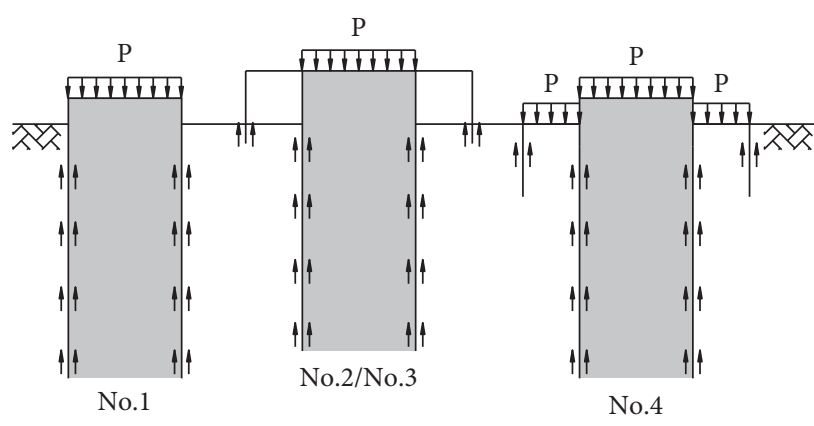

Figure 6: Schematic diagram of suction caisson penetration.

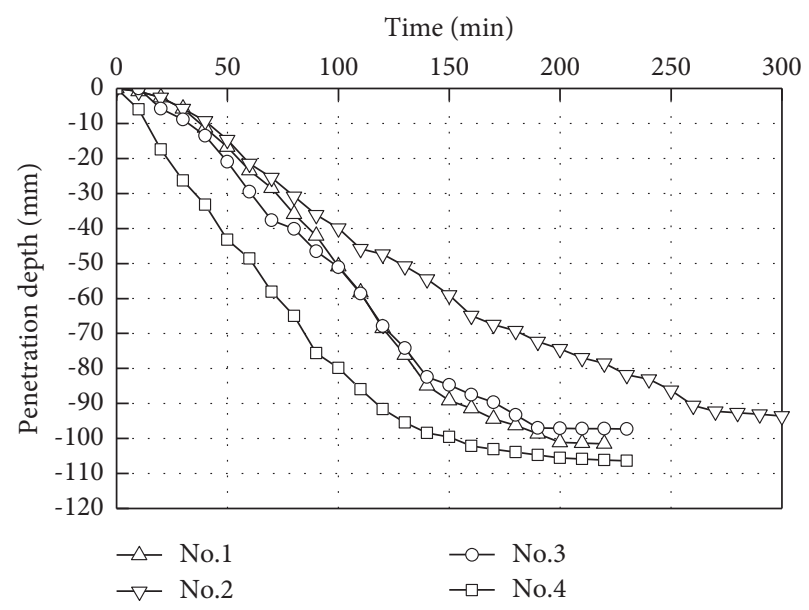

Figure 7: Penetration depth-time curve of suction caissons.

pressure penetration depth, and "soil plug" height are shown in Table 2. The suction caissons after penetration are shown in Figure 8. Obviously, the penetration of low-skirted suction caisson is better than that of conventional ones, which can effectively reduce the height of "soil plug" and improve the bearing capacity of suction caissons.

2.2.3. Penetration Mechanism. The penetration resistance is mainly composed of internal and external friction and end resistance of the suction caisson, as represented by the following formula:

$$
R=Q_{f}+Q_{p}=\sum f_{b} A_{b}+q_{d} A_{p},
$$

where $R$ is the penetration resistance $(\mathrm{kN}) ; Q_{f}$ is the side friction resistance $(\mathrm{kN}) ; Q_{p}$ is the end resistance $(\mathrm{kN}) ; f_{b}$ is the side friction resistance per unit area $(\mathrm{kPa})$, and the undrained shear strength $s_{n}$ can be used for the value; $A_{n}$ is side area of suction caisson $\left(\mathrm{m}^{2}\right) ; q_{4}$ is the end resistance per unit area $(\mathrm{kPa})$, and the value equals to $9 S_{u}$ for clayey soil [31]; $A_{p}$ is total end area of suction caisson $\left(\mathrm{m}^{2}\right)$.

The penetration force of suction caisson is mainly composed of negative pressure and dead-weight, as represented by

$$
S=W+P,
$$

where $S$ is the penetration force $(\mathrm{kN}) ; W$ is dead-weight of suction caisson (including the dead-weight of the guide bar), 
TABle 2: Penetration depth of suction caissons ( $\mathrm{mm}$ ).

\begin{tabular}{lcccc}
\hline $\begin{array}{l}\text { Model } \\
\text { number }\end{array}$ & $\begin{array}{c}\text { Internal compartment } \\
\text { depth }\end{array}$ & $\begin{array}{c}\text { Dead-weight } \\
\text { penetration depth }\end{array}$ & $\begin{array}{c}\text { Negative pressure } \\
\text { penetration depth }\end{array}$ & "Soil plug" height \\
\hline 1 & 240 & 105.5 & 101.5 & 33 \\
2 & 240 & 100.4 & 93.6 & 46 \\
3 & 240 & 102.75 & 97.25 & 40 \\
4 & 240 & 106.6 & 106.4 & 27 \\
\hline
\end{tabular}

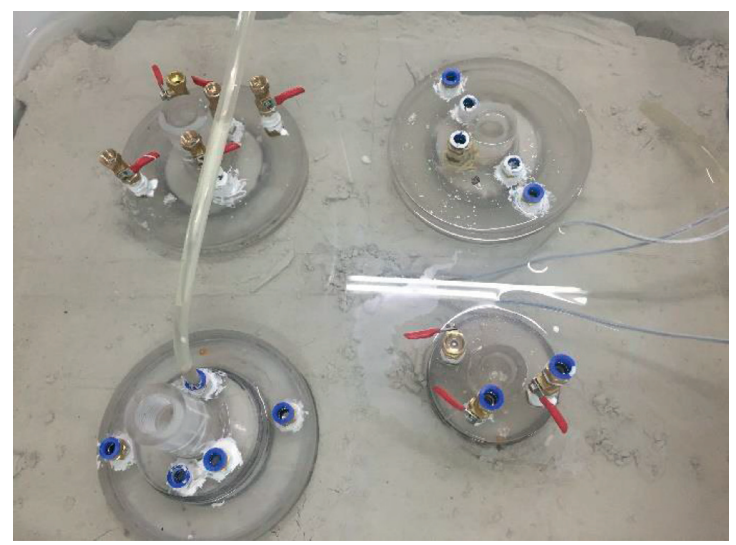

FIgURE 8: Suction caissons after penetration.

and the value is $0.03 \mathrm{kN}$ in this research; $P$ is the suction force $(\mathrm{kN})$, and $P=\pi D^{2} P ; D$ is the diameter of suction caisson; and $P_{a}$ is the negative pressure $(\mathrm{kPa})$.

According to (1) and (2), the penetration force and the resistance of each suction casssion are shown in Table 3.

According to the calculation results in the table above, the penetration resistance $R$ is about $75 \%$ of the penetration force $S$. Obviously, the theoretical calculation of $R$ based on (1) is less than $S$. One reason is that when calculating the maximum penetration resistance, the effective penetration depth outside the suction caisson is adopted, and the friction resistance caused by the "soil plug" inside the suction caisson is ignored. In order to reduce the deviations caused by the above reason, this paper deduces a more practical expression of penetration resistance based on the limit equilibrium theory and the test data. The penetration velocity of suction caisson is slow and uninterrupted during the process of penetration, so the inertia force caused by acceleration is not considered. It is assumed that the penetration force $S$ is equal to the penetration resistance $R$. That is

$$
S=R
$$

A new formula for calculating the penetration resistance $R$ is suggested as follows:

$$
R=2 k_{1} s_{u} A_{b}^{\prime}+k_{2} s_{u} A_{p}+k_{3},
$$

where $A_{b}^{\prime}$ is the lateral area of the suction caisson penetrating into the seabed at a certain moment, and it changes as the penetration depth $h$ increases. $k_{1}, k_{2}, k_{3}$ is three coefficients, and $k_{1}=2, k_{2}=1$, and $k_{3}=-0.2 . S_{u}$ is a function of penetration depth $h$ according to the undrained shear strength profile of soil. Hence, $R$ is actually also a function of $h$.

The penetration depth versus penetration resistance can be determined based on (4), and then the comparison between the calculated result of $R$ and the experimental result of $S$ is shown in Figure 9. The two are basically the same before the "soil plug" is completely formed, which is more in line with the actual situation. The maximus resistance of each suction caisson calculated by (4) is shown in Table 3. The penetration resistance $R$ is about $95 \%$ of the penetration force $S$, which proves that the proposed equation (4) is more reasonable than (1).

2.3. Pullout Tests of Suction Caissons. The self-developed multiangle pullout test device was used to carry out the pullout tests of suction caisson models, as shown in Figure 10. The device is characterized in that the pulley connected to the sliding block can slide or fix at any position on the horizontal bar and vertical bar of the steel frame, so as to realize the change of loading angle. It is allowed to stand for one week after completing the penetration of the suction bucket, and then the suction anchor is pulled along the direction of $45^{\circ}$ from the horizontal plane under the loadcontrol mode with step-by-step loading until the failure of suction caisson. The pullout test of suction caisson is shown in Figure 11.

In order to reduce the influence of the loaded suction caisson on others as much as possible, the loading angle with the horizontal plane which is $45^{\circ}$ can be selected in different direction flexibly. The tension load-time curves for No. 2, No. 3, and No. 4 suction caissons are shown in Figure 12. At the initial stage, the tensile force increases linearly with time. When the uplift bearing capacity of the suction caisson reaches the limit value, it decreases rapidly to near zero in a short time, which indicates that the failure of suction caisson has occurred. The tension load-displacement curves obtained from the test are shown in Figure 13. It can be seen 
TABLE 3: Penetration force and the resistance of suction caissons.

\begin{tabular}{lcccccc}
\hline Model number & $\begin{array}{c}\text { Penetration } \\
\text { depth } H(\mathrm{~m})\end{array}$ & Penetration force $S(\mathrm{kN})$ & $\begin{array}{c}\text { Penetration resistance } \\
R \text { from }(1)(\mathrm{kN})\end{array}$ & $\begin{array}{c}\text { Penetration } \\
\text { resistance } R \text { from }(4) \\
(\mathrm{kN})\end{array}$ & $\begin{array}{c}R / S \\
\text { from }(1)(\%)\end{array}$ \\
\hline 1 & 0.195 & 0.51 & 0.38 & 0.48 & 0.75 \\
2 & 0.193 & 0.50 & 0.37 & 0.47 & 0.74 & 0.94 \\
3 & 0.196 & 0.50 & 0.38 & 0.49 & 0.76 \\
4 & 0.192 & 0.51 & 0.37 & 0.47 & 0.94 \\
\hline
\end{tabular}
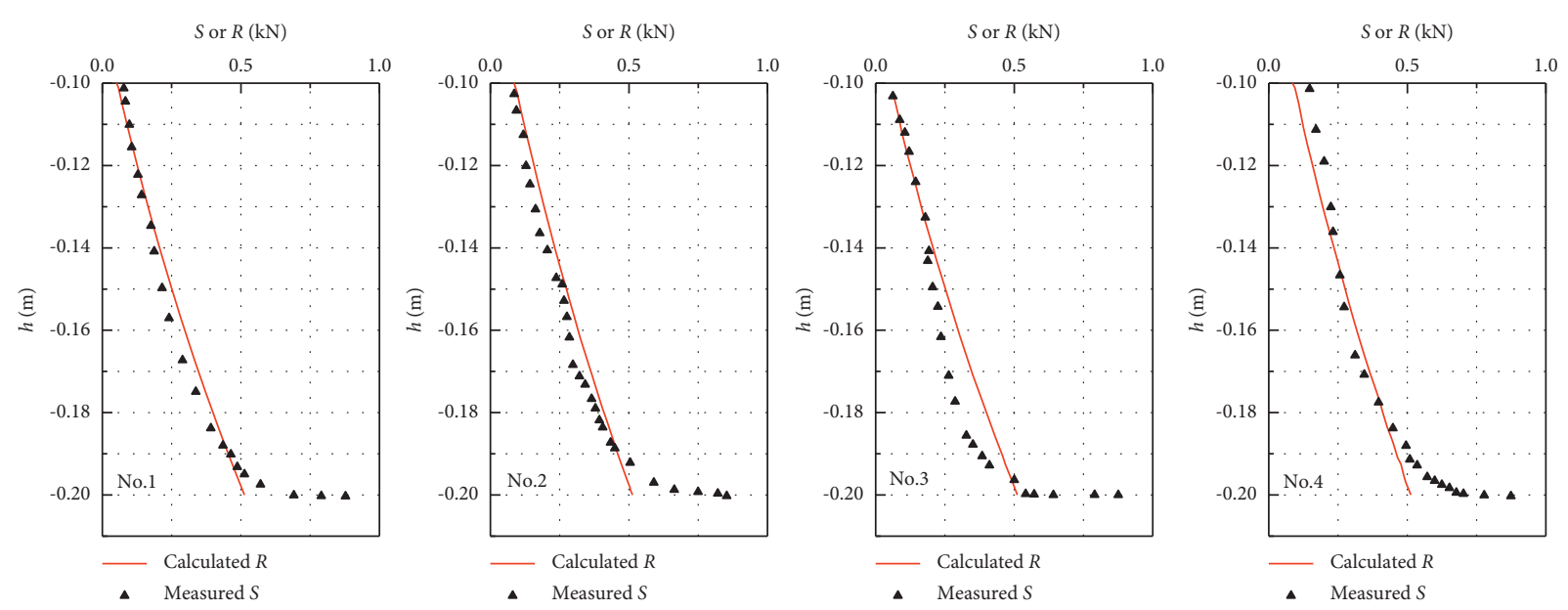

Figure 9: Penetration depth versus penetration force and resistance.

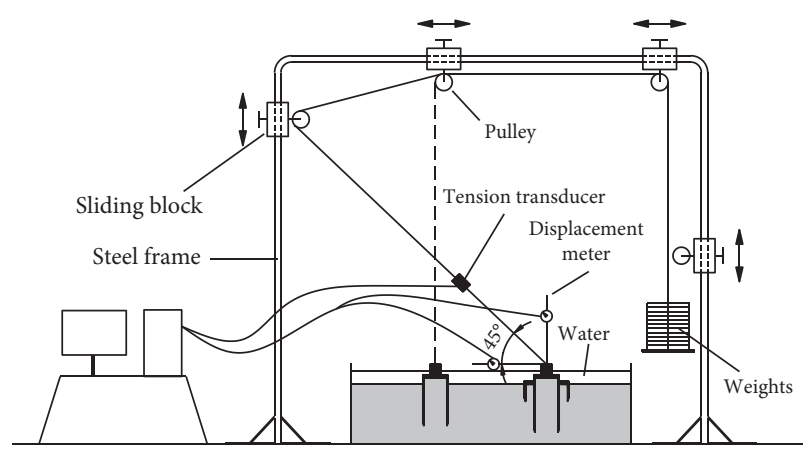

FIGURE 10: Schematic of pullout test device for suction caissons.

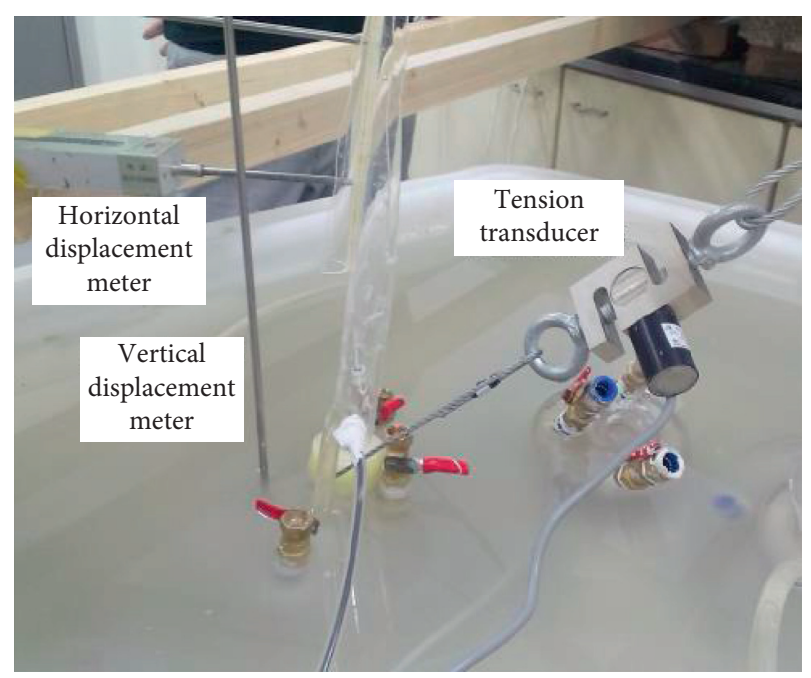

Figure 11: Pullout tests of suction caissons. that the uplift bearing capacity of the suction caisson increases by $32 \%$ when the skirt length increases by $20 \mathrm{~mm}$ comparing with No. 2 and No. 3 suction caissons, which indicates that the skirt length has a significant effect on the uplift bearing capacity. The bearing capacity of the lowskirted suction caisson is $23 \%$ higher than that of the conventional one by comparing No. 3 and No. 4 suction caissons, which indicates that a reasonable height difference between the internal compartment and external compartment of the suction caisson can effectively improve the bearing capacity.

\section{Numerical Simulation of Low-Skirted Suction Caisson under Inclined Loading}

3.1. Three-Dimensional Finite Element Model. A three-dimensional finite element model of low-skirted suction caissons embedded in soils is established based on PLAXIS 3D finite element software. The length, width, and height of soil domain are $40 \mathrm{~m}, 40 \mathrm{~m}$, and $60 \mathrm{~m}$, respectively, which is sufficient to avoid boundary effects on numerical simulation results, as shown in Figure 14. The specific dimensions of low-skirted suction caisson is shown in Table 4. The pile material is assumed to be linear elastic, and the elastic modulus $E=2.1 \times 10^{5} \mathrm{MPa}$, and Poisson's ratio $\mu=0.2$. Mohr Coulomb model is used for soil material, and cohesion $c=1.5 \mathrm{kPa}$, internal friction angle $\varphi=17^{\circ}$, elastic modulus $E=30 \mathrm{MPa}$, Poisson's ratio $\mu=0.2$, and saturated unit weight $\gamma_{\text {sat }}=17.88 \mathrm{kN} / \mathrm{m}^{3}$. The contact element is set at the interface of soil and suction caisson to simulate the interaction between pile and soil. The horizontal constraint is imposed on 


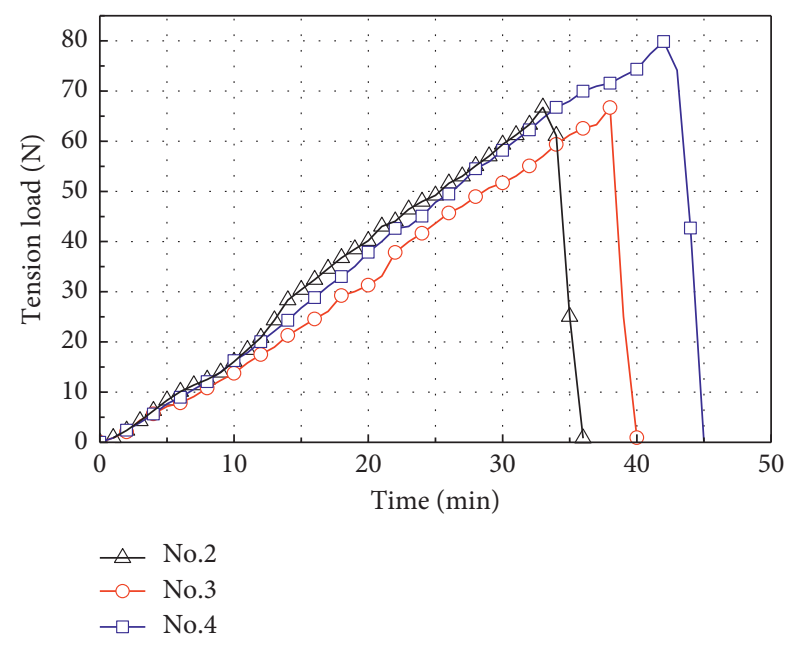

FIgURE 12: Tension load-time curves obtained from the tests.

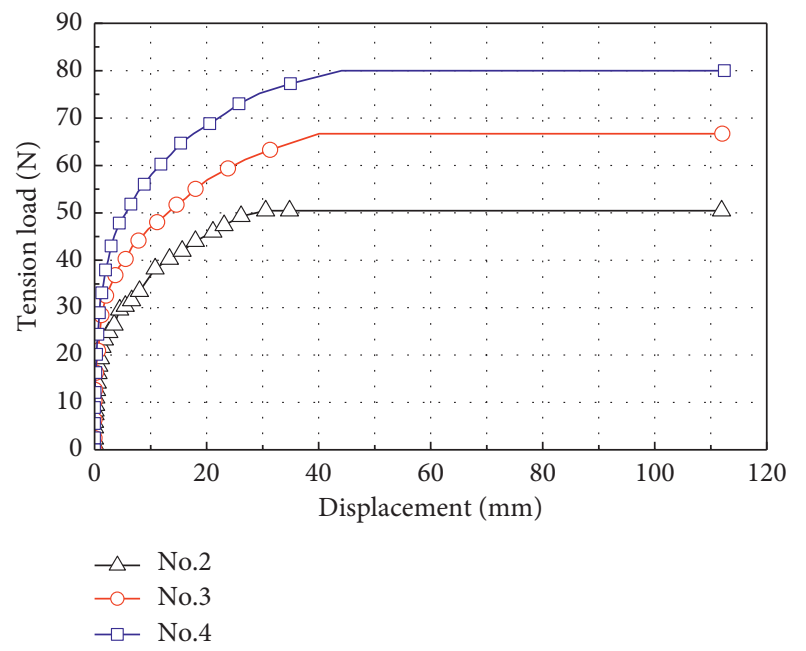

Figure 13: Tension load-displacement curves obtained from the tests.

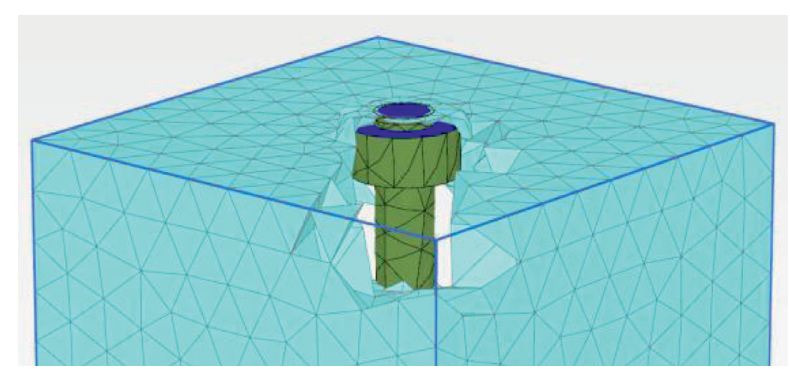

FIGURE 14: Three-dimensional finite element model of low-skirted suction caisson embedded in soils.

TABle 4: Specific dimensions of low-skirted suction caisson finite element model (m).

\begin{tabular}{lccccc}
\hline$D_{2}$ & $H_{1}$ & $D_{1}$ & $H_{2}$ & $H_{3}$ & $t_{2}$ \\
\hline 4 & 12 & 8 & 2 & 2 & 0.05 \\
\hline
\end{tabular}

the side of the model, the fixed constraint is set at the bottom of the model, and the top surface is free. The finite element model is meshed by the automatic meshing technology, and the accuracy of meshing is medium roughness. The inclined tension load is applied to the sidewall of the low-skirted suction caisson. The loading angles $\beta$ are $0^{\circ}, 30^{\circ}, 45^{\circ}, 60^{\circ}$, and $90^{\circ}$ to the horizontal plane, and the loading positions $L$ are 0 , $H_{1} / 2,2 H_{1} / 3,3 H_{1} / 4,5 H_{1} / 6$, and $H_{1}$ from the top of suction caisson, respectively.

3.2. Ultimate Bearing Capacity. For any loading angle, if the ultimate bearing capacity reaches the maximum when the loading point is at a certain position, the position is considered as the best loading point $[19,21]$. Figure 15 shows the curves of the ultimate bearing capacity with the loading position at different loading angles. The ultimate bearing capacity of low-skirted suction caisson first increases and then decreases with the downward movement of the loading point. The ultimate bearing capacity is the smallest when the loading point is located on the top of the caisson and reaches the maximum value at a certain loading postion, and then the bearing capacity becomes smaller and smaller as the loading point moves down. Generally speaking, the best loading point position is kept in the range of $2 \mathrm{H}_{1} / 3$ to $3 \mathrm{H}_{1} / 4$. The best loading point position does not change significantly with the increase of loading angle. When the loading angle is more than $60^{\circ}$, the loading position has little effect on the ultimate bearing capacity, which is consistent with the research results of Bang et al. [32].

The loading angle has a significant effect on the ultimate bearing capacity of the suction caisson, as shown in Figure 16. For a specific loading position, the ultimate bearing capacity decreases with the increase of loading angle, which is mainly due to the fact that the horizontal bearing capacity of the suction caisson is significantly greater than the vertical bearing capacity. The horizontal bearing capacity is mainly provided by the passive Earth pressure, while the vertical bearing capacity is mainly provided by the side friction between the caisson wall and soil. The horizontal component becomes smaller and smaller as the loading angle increases, and the uplift bearing capacity is almost equal to the side friction when the loading angle is $90^{\circ}$. When the loading point is at the top of the caisson, the ultimate bearing capacity reaches the minimum, and the loading angle has little effect on the ultimate bearing capacity.

3.3. Failure Mechanism. The displacement vector of soil around the suction caisson under different loading positions when the loading angle is $30^{\circ}$ is shown in Figure 17. The displacement of suction caisson under inclined loads is shown in Figure 18. When the loading position is above $3 H_{1} / 4$, the displacement of the soil on both passive zone and active zone on the upper part of the suction caisson is significant, and the caisson rotates around a certain position on the lower right side. At this case, the forward overturning failure occurs, and the closer the loading point is to the top of the caisson, the more significant the forward overturning trend is. The rotation center position is lower as the loading position moves down. When the 


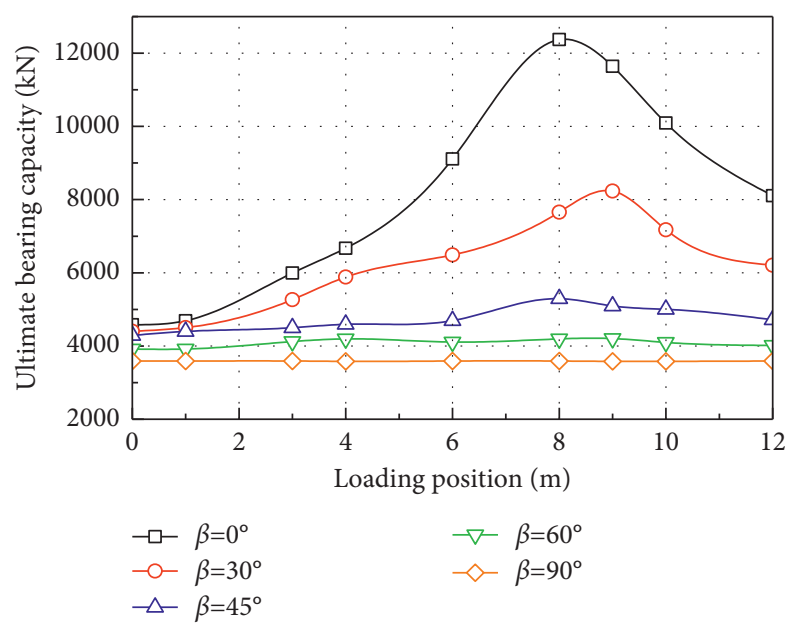

FIGURE 15: Ultimate bearing capacity with the loading position at various loading angles.

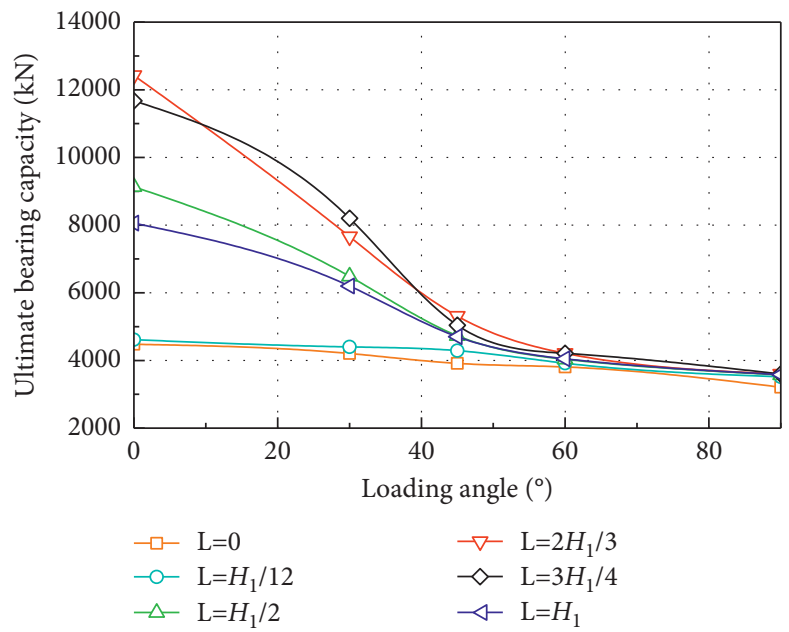

FIGURE 16: Ultimate bearing capacity with the loading angle at various loading positions.

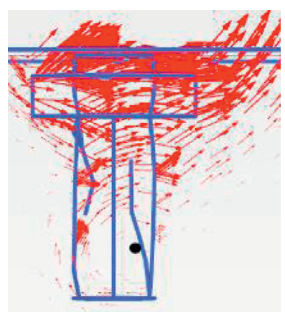

$\mathrm{L}=0$

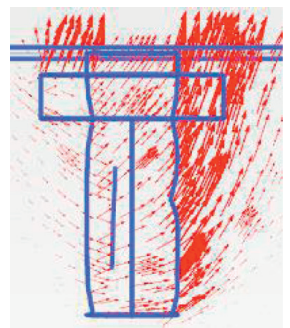

$\mathrm{L}=2 \mathrm{H}_{1} / 3$

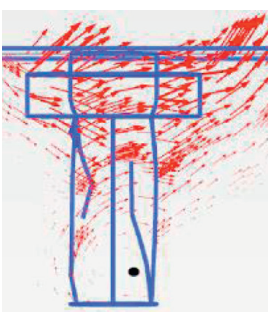

$\mathrm{L}=\mathrm{H}_{1} / 12$

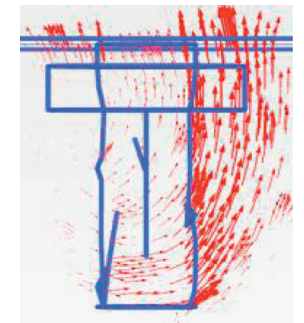

$\mathrm{L}=3 \mathrm{H}_{1} / 4$

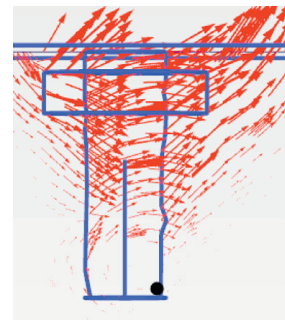

$\mathrm{L}=\mathrm{H}_{1} / 4$

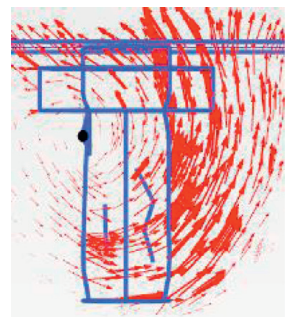

$\mathrm{L}=5 \mathrm{H}_{1} / 6$

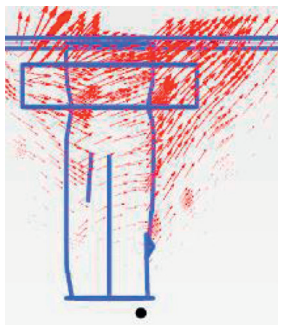

$\mathrm{L}=\mathrm{H}_{1} / 2$

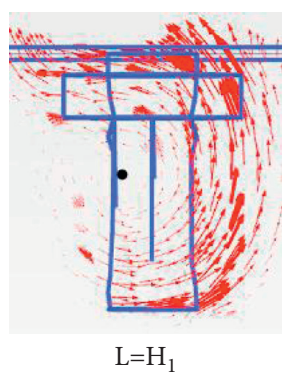

FigURE 17: Displacement vector of soil around the suction caisson under different loading positions $\left(\beta=30^{\circ}\right)$. 


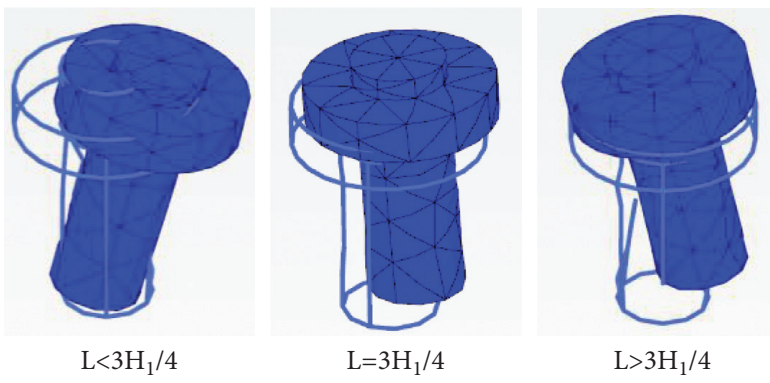

FIGURE 18: Displacement of the suction caisson under inclined loads $\left(\beta=30^{\circ}\right)$.

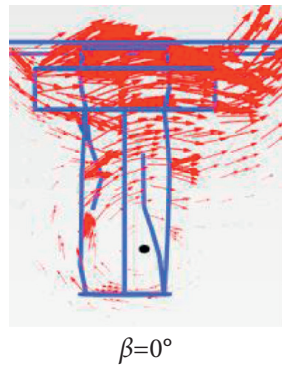

$\beta=0^{\circ}$

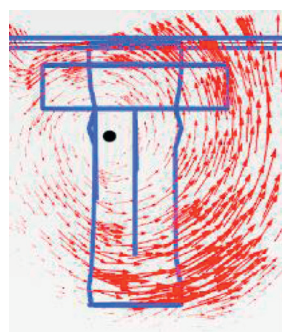

$\beta=0^{\circ}$

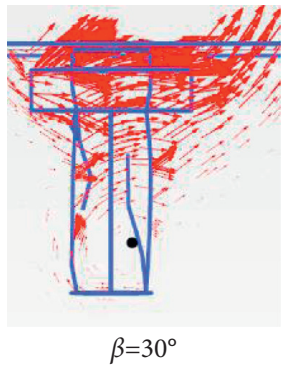

(a)

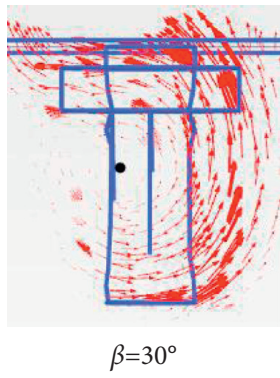

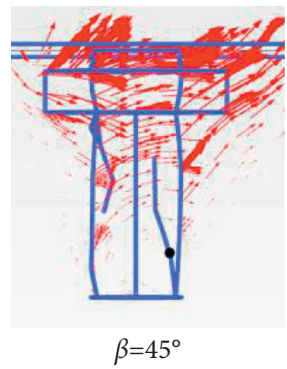
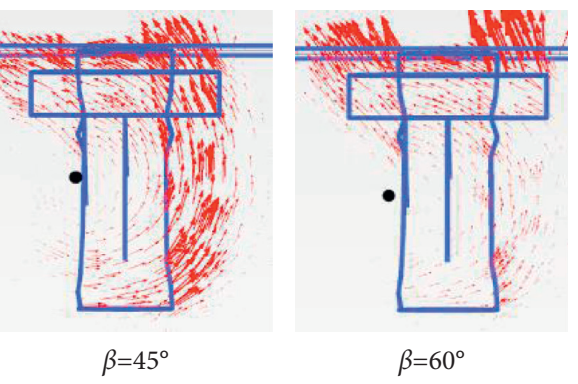

(b)

Figure 19: Displacement vector of soil around the suction caisson under different loading angles: (a) $L=0$ and (b) $L=H_{1}$.

loading position is near $3 \mathrm{H}_{1} / 4$, the soil in the passive zone moves significantly along the whole depth of the suction caisson. In this case, there is no rotation center and translational failure occurs. When the loading position is below $3 H_{1} / 4$, the soil on the passive zone has a significant upward displacement component, and the suction caisson rotates around a position on the upper left side. In this case, the backward overturning failure occurs, and the closer the loading point is to the bottom of the suction caisson, the more obvious the overturning is.

The loading angle has a significant effect on the failure mechanism of the suction caisson, as shown in Figure 19. When the loading position is at the top of the caisson $(L=0)$, the vertical displacement component increases as the loading angle increases, and the center of rotation gradually moves to the right, which is mainly due to the reduction of Earth pressure on the passive side. When the loading position is at the bottom of the caisson $\left(L=H_{1}\right)$, the center of rotation gradually moves to the lower left side of the caisson as the loading angle increases. The main reason is that the Earth pressure on the left side of the caisson gradually decreases with the increase of the loading angle, and then the horizontal displacement component becomes smaller. In a word, the change of the failure mechanism is mainly due to the change of passive Earth pressure and friction between caisson wall and soil.

3.4. Stress Distribution in Limit Equilibrium State. The normal stress distribution around the suction caisson in the limit state is shown in Figure 20. The active and passive Earth pressure intensity distributions are also shown in Figure 20. The normal stress on the right side of the suction caisson (the side under inclined load) is more uniform and larger for the loading angle of $0^{\circ}$. The simulation results of the normal stress within $3 \mathrm{H}_{1} / 4$ of the caisson depth from the caisson top are close to passive soil pressure strength, which indicates that the upper right part of the caisson is in full contact with the soil under great passive Earth pressure. The normal stress on the left side of the suction caisson is relatively small in general, which is due to the clockwise rotation of the caisson around a certain point during loading, so that the Earth pressure on the left upper part of 


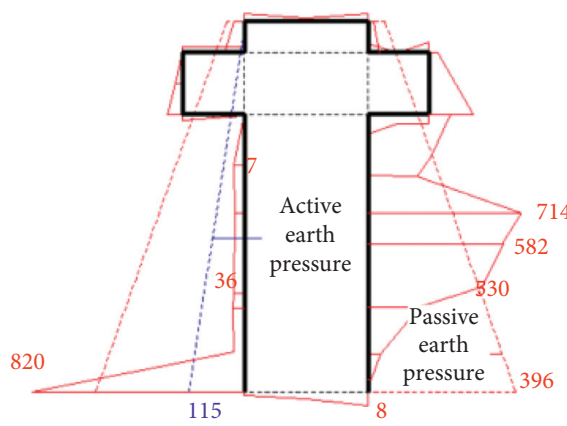

(a)

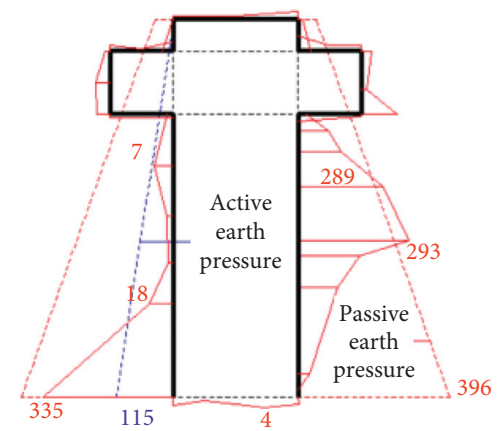

(b)

Figure 20: Normal stress profile of low-skirted suction caisson under inclined load (kPa): (a) $\beta=0^{\circ}$ and $L=0$; (b) $\beta=45^{\circ}$ and $L=0$.

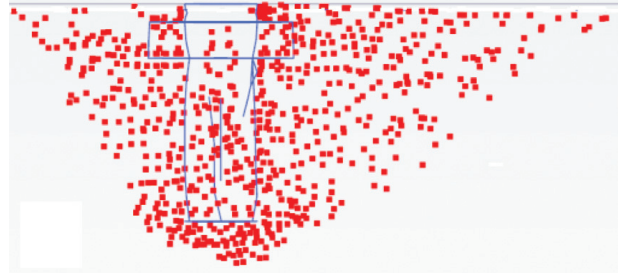

(a)

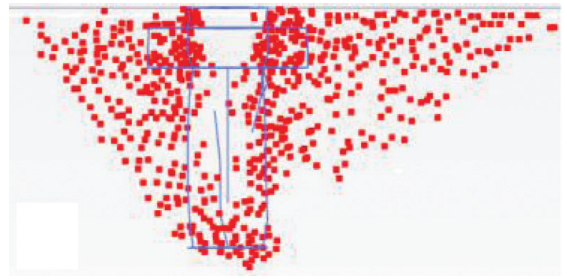

(b)

Figure 21: Plastic deformation diagram of low-skirted suction caisson under inclined load: (a) $\beta=0^{\circ}$ and $L=0$; (b) $\beta=45^{\circ}$ and $L=0$.

the caisson changes from the original static Earth pressure to the active Earth pressure. However, it is worth noting that the normal stress in the lower left corner of the suction caisson almost exceeds the passive Earth pressure strength due to the passive compression of soils caused by the rotation of the caisson. When the loading angle is in the range from $30^{\circ}$ to $60^{\circ}$, the distribution of Earth pressure is different with that of $0^{\circ}$. The case of $45^{\circ}$ is shown in Figure 20. Obviously, the normal stress is generally less than that of the loading angle of $0^{\circ}$, which is mainly due to the tendency of both clockwise rotation and upward movement of the suction casssion. In addition, it also indicates that the bearing capacity of the suction caisson is mainly provided by the passive Earth pressure and vertical friction between caisson wall and soil. The plastic deformation area of the soil is in an inverted cone shape, as shown in Figure 21. The plastic area on the right side of the caisson is obviously larger than that on the left side of the suction caisson because of the larger stress on the right side. The plastic area on the passive side of the loading angle of $0^{\circ}$ is obviously larger than that of $45^{\circ}$ because of the larger horizontal stress component.

\section{Conclusions}

Penetration and pullout capacity of low-skirted suction caissons was investigated by performing model tests and finite element analysis. The key conclusions can be summarized as follows:

(1) A new type of cross-shaped skirted suction caisson, named as the low-skirted suction caisson, is invented. Compared with the traditional suction caissons, the new suction caisson can effectively reduce the height of "soil plug" because a certain height difference is set between internal and external compartments of the suction caisson, and the double compartment negative pressure penetration is adopted. The low-skirted suction caisson can effectively improve the bearing capacity, and it is about $23 \%$ higher than that of the conventional one.

(2) The penetration resistance is mainly composed of internal and external friction and end resistance of the suction caisson. The penetration force of suction caisson is mainly composed of negative pressure and dead-weight. A new formula for calculating the penetration resistance is suggested based on the limit equilibrium theory and the test data, which can consider the change of the lateral area of the suction caisson during penetration.

(3) The ultimate bearing capacity of low-skirted suction caisson first increases and then decreases with the downward movement of the loading point. Generally speaking, the best loading point position is kept in the range from $2 H_{1} / 3$ to $3 H_{1} / 4$. The best loading point position does not change significantly with the increase of loading angle. When the loading angle is more than $60^{\circ}$, the loading position has little effect on the ultimate bearing capacity.

(4) The loading angle has a significant effect on the ultimate bearing capacity of the suction caisson. For a specific loading position, the ultimate bearing 
capacity decreases with the increase of loading angle, which is mainly due to the fact that the horizontal bearing capacity of the suction caisson is significantly greater than the vertical bearing capacity.

(5) When the loading position is above $3 H_{1} / 4$, the forward overturning failure of suction caisson occurs. When the loading position is near $3 H_{1} / 4$, the translational failure occurs. When the loading position is below $3 H_{1} / 4$, the backward overturning failure occurs. The change of the failure mechanism is mainly due to the change of passive Earth pressure and friction between caisson wall and soil.

(6) The bearing capacity of the suction caisson is mainly provided by the passive Earth pressure and vertical friction between caisson wall and soil. The normal stress distribution around the suction caisson and the plastic area on the passive side of caisson in the limit state is related to horizontal and vertical components of inclined loads.

\section{Data Availability}

All data and information are available within the article. Additional data or information can be obtained from the corresponding author upon request.

\section{Conflicts of Interest}

The authors declare that there are no conflicts of interest regarding the publication of this article.

\section{Acknowledgments}

The authors gratefully acknowledge financial support from the Science and Technology Projects of POWERCHINA Huadong Engineering Corporation Limited (no. KY2020KC-08-01-2021) and the Tianjin Municipal Natural Science Foundation (no. 20JCYBJC00570).

\section{References}

[1] K. H. Anderson, "Bearing capacity under cyclic loadingoffshore, along the coast, and on land," Canadin Geotechnical Journal, vol. 46, no. 5, pp. 513-535, 2009.

[2] B. W. Byrne, G. T. Houlsby, and C. Martin, "Suction caisson foundations for offshore wind turbines," Journal of Wind Engineering, vol. 26, no. 2, pp. 145-155, 2002.

[3] G. T. Houlsby, L. B. Ibsen, and B. W. Byrne, "Suction caissons for wind turbines," Frontiers in Offshore Geotechnics, vol. 44, pp. 75-93, 2005.

[4] W. Chen, H. Zhou, and M. F. Randolph, "Effect of installation method on external shaft friction of caissons in soft clay," Journal of Geotechnical and Geoenvironmental Engineering, vol. 135, no. 5, pp. 605-615, 2009.

[5] P. M. Asa and K. H. Andersen, "Skirted foundation for offshore structure," in Proceedings of the $9^{\text {th }}$ Offshore South East Asia Conference, pp. 1-7, World Trade Center, Singapore, Asia, December 1992.

[6] E. C. Clukey, M. J. Morrison, J. Gamier, and J. F. Corte, "The response of suction caisson in normally consolidated clay to cyclic TLP loading conditions," in Proceedings of of Shore
Technology Conference, pp. 909-918, Houston, TX, USA, May 1995.

[7] J. H. Zhang, G. L. Sun, D. Yan, and X. B. Lu, "Geotechnical centrifuge modeling on suction caissons in offshore engineering," Ocean Engineering, vol. 2, no. 22, pp. 90-97, 2004.

[8] B. Sukumaran, W. O. McCarron, P. Jeanjean, and H. Abouseeda, "Efficient finite element techniques for limit analysis of suction caissons under lateral loads," Computers and Geotechnics, vol. 24, no. 2, pp. 89-107, 1999.

[9] J. Cao, R. Phillips, and R. Popescu, "Numerical analysis of the behavior of suction anchors in clay," International Journal of Offshore and Polar Engineering, vol. 13, no. 2, pp. 154-159, 2003.

[10] H. Monajemi and H. A. Razak, "Finite element modeling of suction anchors under combined loading," Marine Structures, vol. 22, no. 4, pp. 660-669, 2009.

[11] L. B. Ibsen, K. A. Larsen, and A. Barari, "Calibration of failure criteria for bucket foundations on drained sand under general loading," Journal of Geotechnical and Geoenvironmental Engineering, vol. 140, no. 7, 2014.

[12] J. Ahn, H. Lee, and Y.-T. Kim, "Holding capacity of suction caisson anchors embedded in cohesive soils based on finite element analysis," International Journal for Numerical and Analytical Methods in Geomechanics, vol. 38, no. 15, pp. 1541-1555, 2014.

[13] L. C. Hung and S. R. Kim, "Evaluation of vertical and horizontal bearing capacities of bucket foundations in clay," Ocean Engineering, vol. 52, pp. 75-82, 2012.

[14] W. Deng and J. P. Carter, "A theoretical study of the vertical uplift capacity of suction caissons," International Journal of Offshore and Polar Engineering, vol. 12, no. 2, pp. 89-97, 2002.

[15] M. Iskander, S. El-Gharbawy, and R. Olson, "Performance of suction caissons in sand and clay," Canadian Geotechnical Journal, vol. 39, no. 3, pp. 576-584, 2002.

[16] M. F. Bransby and G.-J. Yun, "The undrained capacity of skirted strip foundations under combined loading," Géotechnique, vol. 59, no. 2, pp. 115-125, 2009.

[17] S. Gourvenec and S. Barnett, "Undrained failure envelope for skirted foundations under general loading," Géotechnique, vol. 261, no. 3, pp. 236-270, 2011.

[18] G. Yun and M. F. Bransby, "The undrained vertical bearing capacity of skirted foundations," Soils and Foundations, vol. 47, no. 3, pp. 493-505, 2007.

[19] S. Keawsawasvong and B. Ukritchon, "Finite element limit analysis of pullout capacity of planar caissons in clay," Computers and Geotechnics, vol. 75, pp. 12-17, 2016.

[20] D. S. K. Mana, S. Gourvenec, and C. M. Martin, "Critical skirt spacing for shallow foundations under general loading," Journal of Geotechnical and Geoenvironmental Engineering, vol. 139, no. 9, pp. 1554-1566, 2013.

[21] B. Ukritchon and S. Keawsawasvong, "Undrained pullout capacity of cylindrical suction caissons by finite element limit analysis," Computers and Geotechnics, vol. 80, pp. 301-311, 2016.

[22] D. C. Sun, S. H. Zhang, and H. J. Yu, "Characteristic analysis of bucket foundation during penetration by suction," Coastal Engineering, vol. 18, no. 1, pp. 33-36, 1999.

[23] R. D. Zhu, H. Q. Gao, and X. B. Ma, "Offshore bucket foundation model penetration by pressure and suction test research," Coastal Engineering, vol. 18, no. 1, pp. 33-36, 1999.

[24] D. Li, L. Feng, and Y. Zhang, "Model tests of modified suction caissons in marine sand under monotonic lateral combined loading," Applied Ocean Research, vol. 48, pp. 137-147, 2014. 
[25] D. Li, Y. Zhang, L. Feng, and Y. Gao, "Capacity of modified suction caissons in marine sand under static horizontal loading," Ocean Engineering, vol. 102, pp. 1-16, 2015.

[26] D. Li, S. Ma, and Y. Zhang, "Undrained pullout capacity of modified suction caisson in clay by finite element limit analysis," Marine Georesources \& Geotechnology, vol. 37, pp. 1-10, 2017.

[27] H. J. Liu and H. J. Li, "A new suction anchor foundation of the Yellow River Delta offshore wind power," Journal of Ocean University of China, vol. 44, no. 7, pp. 71-76, 2014.

[28] H. Li, H. Liu, and S. Liu, "Dynamic analysis of umbrella suction anchor foundation embedded in seabed for offshore wind turbines," Geomechanics for Energy and the Environment, vol. 10, pp. 12-20, 2017.

[29] R. Liu, G. Chen, J. Lian, and H. Ding, "Vertical bearing behavior of the composite bucket shallow foundation of offshore wind turbines," Journal of Renewable and Sustainable Energy, vol. 1, pp. 717-728, 2015.

[30] J. Lian, L. Sun, J. Zhang, and H. Wang, "Bearing capacity and technical advantages of composite bucket foundation of offshore wind turbines," Transactions of Tianjin University, vol. 17, no. 2, pp. 132-137, 2011.

[31] ANSI/API RP 2GEO-2011, Geotechnical and Foundation Design Considerations, American Petroleum Institute, New York, NY, USA, First edition, 2011.

[32] S. Bang, K. D. Jones, K. O. Kim, Y. S. Kim, and Y. Cho, "Inclined loading capacity of suction piles in sand," Ocean Engineering, vol. 38, no. 7, pp. 915-924, 2011. 